\title{
シート状プラスチック片の静電分離
}

\section{The Triboelectric Separation for Plastic Sheets}

\author{
竹下 武 成 ${ }^{*}$, 渥美 邦 夫 ${ }^{* *}$, 岩 崎 由 浩*, 原田 敏 宏* \\ Takenari TAKESHITA, Kunio ATSUMI, Yoshihiro IWASAKI, Toshihiro HARADA
}

\begin{abstract}
An apparatus for separating a specified plastic from other kinds was devised. It consisted of a triboelectric section and a separating section with both polarities. Various plastic sheets were frictionally electrified in the fluidized bed and then were blown off into the electrode unit, in which they were separated according to their own polarity.

The recovery of plastics was more than $70 \%$ beyond the electric field strength of $100 \mathrm{kV} / \mathrm{m}$, and the weight ratio of recovered plastics was more than $80 \%$ in the separation of the four kinds of plastics.
\end{abstract}

Key Words : Plastic Sheets, Static Electricity, Triboelectric Series, Electrostatic Separation, Blowoff Air Velocity

\section{1. 緒 言}

今，資源のリサイクルは，ごみ問題や資源の節約の 観点から, その必要性が求められている。静岡県では 紙産業が盛んで膨大な紙類が廃棄物として排出されて いる。排出される廃棄物は, 主としてプラスチックが コーティングされている紙で, 焼却処分すると発熱量 が大きく燃焼炉を傷める上に，ポリ塩化ビニル等の塩 素を含むプラスチックの場合は有害なガスを発生し, 環境に悪影響を与える。これらの廃棄物をリサイクル するには，廃棄物中に含まれている紙とシート状のプ ラスチック類を分離し，さらにそのプラスチックを種 類別に分離する必要がある。

プラスチックの分離には比重分離, 溶剂溶解分離, 溶融分離, 摩擦帯電などを利用した静電分離などがあ $ろ^{(12)}$ 。プラスチックの静電分離は, Kail \& Salz 社 (ドイッ) がESTA プロセスにより混合廃プラスチッ クの分離に成功して以来, 乾式であることと同一比重 のものでも分離できることから注目されている ${ }^{4)} 。 ま$

1997年6月 13 日受付

化学工学会第29回秋季大会（1996 年 9 月，京都）にて一部発表 $*$ 静岡大学工学部物質工学科

（广432-8011 静岡県浜松市城北 3-5-1）TEL 053-478-1168

Department of Materials Science and Engineering, Shizuoka University

(3-5-1 Johoku, Hamamatu-shi, Shizuoka, 432-8011) **静岡大学工学部システム工学科

（市432-8011 静岡県浜松市城北 3-5-1) TEL 053-478-1205 Department of System Engineering. Shizuoka Univesity (3-5-1 Johoku, Hamamatu-shi. Shizuoka, 432-8011)
た国内でも電線総合技術センターが, 電線被覆材であ るポリエチレンとポリ塩化ビニルの分離テストを行 い, 高い分離効果を得ている ${ }^{2)}$ 。しかし，これらの静 電分離は球状, ホース状などに対するもので, シート 状のものに対する分離技術はシート状プラスチックの 重力落下が難しいため，まだ報告されていない。

そこで本研究では，異種のプラスチック細片を流動 層で摩擦帯電させ, 帯電状態を保ったまま電極部に飛 散して分離捕集する装置を製作し，基礎実験を行った 結果, 回収率及び種類別枚数分率 (純度) など分離に 関する評価を検討したので報告する。

\section{2. 分離の原理}

二つの物質を摩擦帯電させると一方の物質が正に, もう一方が負に帯電する。これを異なった物質で繰り 返していくと負帯電から正帯電まで物質相互の順列が 決まる。これを帯電列 ${ }^{5}$ と言い古くから知られている が, 測定する雲囲気条件で順列が入れ替わる。プラス チックの比重等の物性はかなり類似しているが，プラ スチック同士を摩擦すると必ず一方が正に, 他方が負 に帯電する。摩擦帯電させるには, 流動層によって異 なった粒子同士を摩擦帯電させる方法, 固定壁と物質 を摩擦して帯電させる方法 ${ }^{3)}$ などが考えられる。本研 究で分離回収する物質はシート状プラスチック細片で それらだけでは流動化は困難で，また固定壁との摩擦 も行い難い。そこで本研究では, 流動媒体として帯電 列が二種類のシート状プラスチック細片の中間に位置 
Table 1 Characteristics of plastic sheets

\begin{tabular}{lcc}
\hline \multicolumn{1}{c|}{ Materials } & Density $\left(\mathrm{kg} / \mathrm{m}^{3}\right)$ & Thickness $(\mu \mathrm{m})$ \\
\hline Polyvinyl chloride (PVC) & 1410 & 40 \\
Polyethylene terephthalate (PET) & 1380 & 23 \\
Polyethylene (PE) [black] & 950 & 20 \\
Polyethylene (PE) [transparence] & 950 & 29 \\
Polypropylene (PP) & 910 & 29 \\
\hline
\end{tabular}

Table 2 Characteristics of fluidized media

\begin{tabular}{lc|c}
\hline \multicolumn{1}{c|}{ Materials } & $\begin{array}{c}\text { Particle diameter } \\
(\mathrm{mm})\end{array}$ & $\begin{array}{l}\text { Minimum fluidizing } \\
\text { velocity }(\mathrm{m} / \mathrm{s})\end{array}$ \\
\hline Polyvinyl chloride (PVC) & $1.2 \sim 1.7$ & 0.320 \\
Polyethylene (PE) & $1.0 \sim 1.7$ & 0.437 \\
Polystyrene (PS) & $1.0 \sim 1.7$ & 0.290 \\
\hline
\end{tabular}

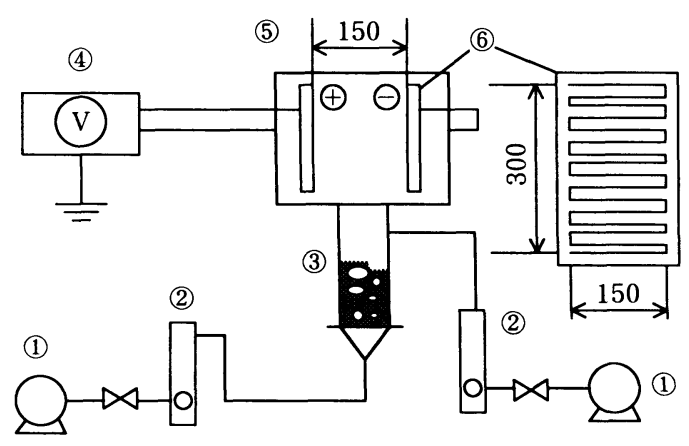

(1) Blower (2) Flowmeter (3) Fluidized bed

(4) High voltage power pack (5) Electric separator

(6) Electrode

Fig. 1 Outline of experimental apparatus ( $\mathrm{mm}$ )

するプラスチック粒子を用い，複数種類の混合プラス チックを流動化し，摩擦帯電させる。正または負に帯 電したシート状プラスチック細片のみを流動層上部に ある電極部に飛散させ，それぞれ対応する電極に引き 奇せて分離回収する。

\section{3．実験装置及び方法}

実験装置の概略を Fig. 1 に示す。装置は搭径 27.5 $\mathrm{mm}$, 塔高 $400 \mathrm{~mm}$ の塩化ビニル製流動塔内で摩擦帯 電を行う流動層部と, $0 \sim 30 \mathrm{kV}$ の範囲内で変化させ ることのできる平行電極板（間隔 $150 \mathrm{~mm}$ ) でシート 状プラスチック細片の分離を行う電極部に分けられ る。なお流動塔上部で塔壁にシートの付着がみられた ので，塔頂から $206 \mathrm{~mm}$ の間に $2 \mathrm{~mm}$ の穴を 48 個開 け，空気を吹き込み，付着を防いだ。
Table 3 Experimental conditions

\begin{tabular}{ll} 
Air velocity at friction $(\mathrm{m} / \mathrm{s})$ & 0.6 \\
Air velocity at flying $(\mathrm{m} / \mathrm{s})$ & $1.55,1.60$ \\
Added voltage $(\mathrm{kV})$ & $5,10,15,20$ \\
\hline
\end{tabular}

帯電防止剤（スリーボンド(懒製パンドー29A）を 塗布して乾燥させた流動塔に, 直流式除電器（カスガ (株製 KD-110) を用いて除電した被分離シート状プ ラスチック細片 (20枚) と流動媒体 (20g) を充填し, 十分な混合状態を得るため気流速度をプラスチック細 片が飛散しない範囲内でなるへく上限である流動媒体 の流動化開始速度の 1.6 倍に設定し，またプラスチッ ク細片の回収率が一定となる最短時間, すなわち 1 分 間流動化させて摩擦帯電を行う。その後, 被分離シー ト状プラスチック細片の飛散気流速度以上に流速を上 げて平行電極板間に飛散させ分離捕集する。なお温度 $20 \pm 3{ }^{\circ} \mathrm{C}$, 相対湿度 $40 \pm 5 \%$ 範囲で実験を行い, 実 験回数は 5 回で, 後の回収率は 5 回の平均值を用いた が，誤差は土 $8 \%$ \%っった。

被分離シート状プラスチック細片として市販のシー トを $7 \mathrm{~mm}$ 角の大きさにカットしたものを使用し，物 性については Table 1 に示した。また流動媒体粒子は バージンプラスチックを粉砕したものを使用し，その 物性を Table 2 に，実験条件を Table 3 に示した。

上記の方法で分離を行うにはプラスチック類の帯電 列3.5) と, シート状プラスチック細片の飛散空気速 度 $^{6)}$ を知る必要がある。用いたシート状プラスチック 細片及び流動媒体の内，二種類つうつを摩擦帯電させた 結果，Fig. 2 に示すような帯電列を得た。 


\begin{tabular}{l|l}
\hline \multicolumn{1}{c|}{ Materials } & $(-) \leftarrow$ Triboelectric position $\rightarrow(+)$ \\
\hline PVC sheet & \\
PVC particle & : Fluidized media \\
PET sheet & \\
PE particle & \\
PE sheet(black) & PS particle \\
PE sheet(transparence) & \\
PP sheet &
\end{tabular}

Fig. 2 Triboelectric series

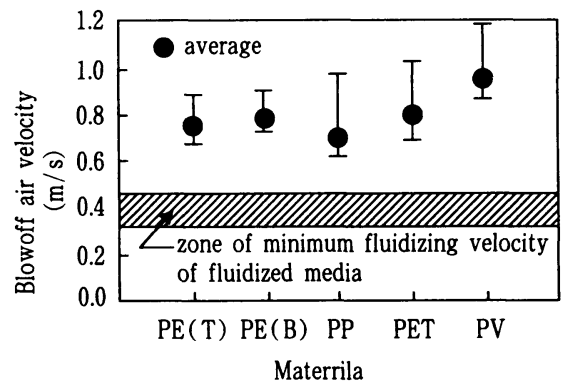

Fig. 3 Blowoff air velocity for plastics sheets

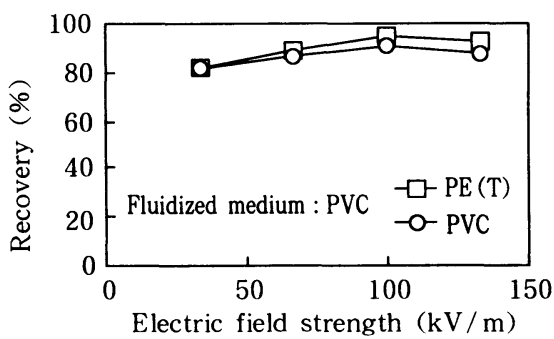

Fig. 4 Recovery of PE (T) and PVC in the separation of two materials

Fig. 3 にシート状プラスチック細片の飛散空気速度 を示す。飛散空気速度には幅があり，分離実験では最 大值以上の気流速度で飛散させたが，飛散するものは 瞬時に飛び出すが，塔壁に付着したものは流動媒体に より剥がされて 1 分程度で飛び出すものと，永久に付 着しているものがあった。

\section{4. 実験結果と考察}

\section{1 二種類のプラスチックの分離}

分離の評価は次のように回収率を定義して，各電極 板方向で回収されるべき種類について求めた。

回収率 $(\%)=\frac{\text { 一種類のプラスチックの回収枚数 }}{\text { 一種類のプラスチックの充塡枚数 }} \times 100$

なお，後に三種類，四種類の分離の結果を示すが，二

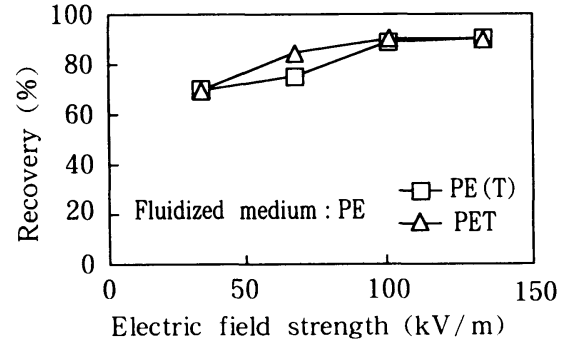

Fig. 5 Recovery of PE ( T) and PET in the separation of two materials

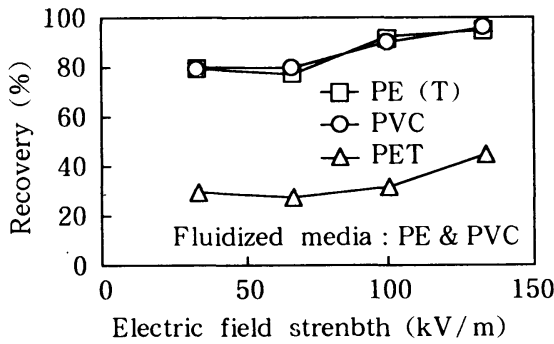

Fig. 6 Recovery of PE (T), PET and PVC in the separation of three materials (undischarged electricity at the secondary separation)

回目の回収率（最終結果）を求める場合の上式の分母 は一回目で得られた枚数を用いた。

Fig.4に，PVC とPE (透明)の分離に対する回収率 と電界強さの関係を示した。いずれのプラスチック細 片においても 80 \%以上の回収率が得られており, クーロン力（=電荷量 $\times$ 電界強さ）により電界強さ が大きくなると回収率も上昇する傾向にあるが, $100 \mathrm{kV} / \mathrm{m}$ を超えても回収率の增加はほとんど見られ ない。回収率が $100 \%$ に達しないのは, 電界強さが低 い時には自重の影響もあるが，主にプラスチック細片 粒子同士の接触により無電荷の中性に近つくこと，プ ラスチック細片の流動壁への付着，さらに流動塔壁と の摩擦により逆方向に帯電することが原因と考えられ る。Fig. 5に, PETとPE（透明）の分離に対する回収 率と電界強さの関係を示した。先述したPVC とPE （透明）の分離に比べると回収率は低く，PET と他の プラスチック細片の組み合わせにおいてもほぼ同様 の結果が得られている。これは本実験で使用した PET が他のプラスチック細片に比べて，仕込み時に おける完全な除電ができないためと考えられる。

\section{2 三種類のプラスチックの分離}

PVC, PET, PE (透明) の三種類のプラスチック を分離するために，先ず流動媒体として PE 粒子を用 


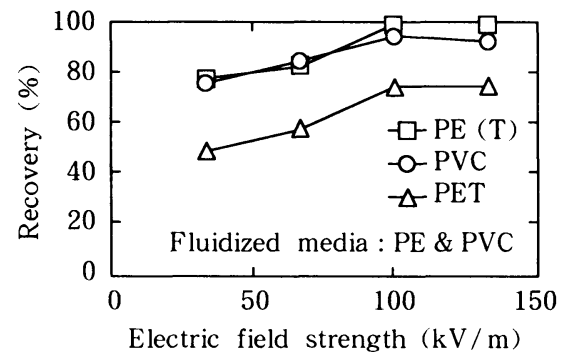

Fig. 7 Recovery of PE (T), PET and PVC in the separation of three materials (discharged electricity at the secondary separation)

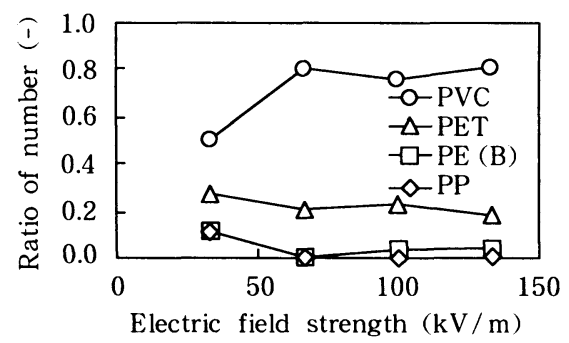

(a) Purity of PVC

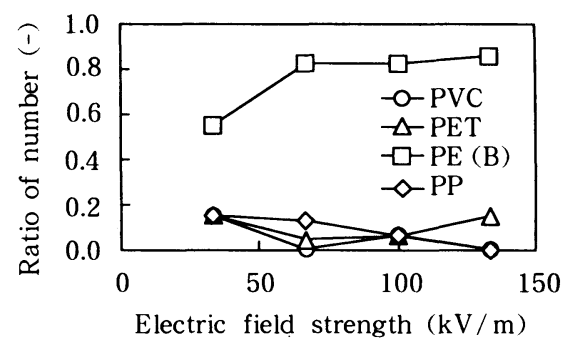

(c) Purity of PE (B)

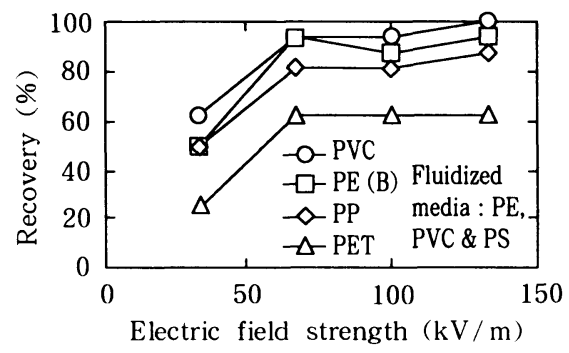

Fig. 8 Recovery of PVC, PET, PE (B) and PP in the separation of four materials

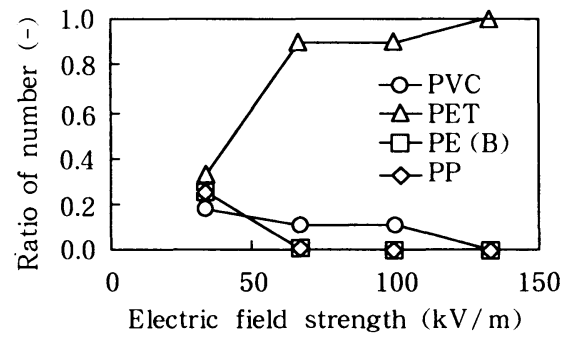

(b) Purity of PET

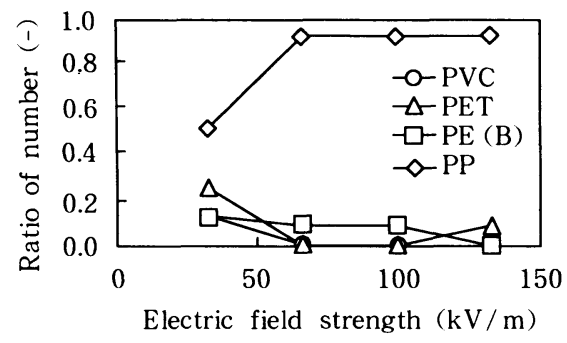

(d) Purity of PP

Fig. 9 Purity of recovered materials in the separation among PVC, PET, PE (B) and PP

いてPE（透明）と他のプラスチック細片を分離し，そ の後, 流動媒体として PVC 粒子を用いてPVC と PET を分離した。Fig.6にPVC, PET，PE（透明）の分 離に対する回収率と電界強さの関係を示した。 PET 細片の回収率がかなり悪いのは, PVCとPETの 分離に際して細片の除電を行わなかった結果であり, 二回目の分離で直流式除電器を用いてプラスチック細 片を除電した場合の結果を Fig. 7に示すが，かなりの 回収率の向上がみられる。PET 細片は, 一回目の摩 擦帯電でマイナスに帯電したものを二回目の摩擦帯電 ではプラスに帯電させなければならないが，放電し難 い性質を持っていて二回目の摩擦帯電前に他の粒子に
比べて十分放電されず，マイナスに帯電したものが残 っているためと思われる。

\section{3 四種類のプラスチックの分離}

PVC, PET, PE (黒), PPの四種類のプラスチッ クを分離するために，PE 粒子を流動媒体に用いて PVCとPETのグループと, PE (黒) とPPのグループ とに分け，その後，PVCとPETの細片をPVC流動媒 体粒子を用いて，またPE（黒）とPPの細片をPS流動 媒体粒子を用いて分離した。その結果を回収率と電界 強さの関係を用いて Fig. 8に示したが, PET細片と電 界強さ $33 \mathrm{kV} / \mathrm{m}$ を除けば，ほぼ $70 \%$ 以上の回収率が 得られている。 
次に分離回収されるべく目標の一種類のプラスチッ ク中に他のプラスチックが混在している割合, すなわ ち純度を調べるために, 最終分離における単一電極側 に回収されたプラスチックの各種類を枚数の分率で次 式のように表した。

$$
\text { 枚数分率 }(-)=\frac{\text { 一種類のプラスチックの回収枚数 }}{\text { 全種類のプラスチックの回収枚数 }}
$$

Fig.9に, PVC, PET, PE (黒), PPの分離回収 を目的とした枚数の分率と電界強さの関係を示し た。それぞれ目的の成分以外の混入割合は電界強さ $33 \mathrm{kV} / \mathrm{m}$ を除けば，はぽ $20 \%$ 以下の枚数分率となっ ている。Fig. 9 の（a), (b) はPVCとPETを分離す るための二回目の分離操作でそれぞれの電極に回収 された枚数分率を示したものであるが, 先述のように PET の摩擦帯電に対する特異な性質のため，お互い に混在する割合が多くなっている。

\section{5. 結言}

重力落下等の方法では分離の難しいシート状プラス チック細片を流動層で摩擦帯電させ, 帯電状態を保っ たまま直上の電極部に飛散させて分離捕集する回分式 装置を製作して実験を行い, 電界強さ $100 \mathrm{kV} / \mathrm{m}$ 以上 で回収率 $70 \%$ 以上の結果が得られた。また四種のプ ラスチックの種類別分離ではそれぞれのプラスチック で $80 \%$ 以上の枚数分率（純度）が得られたことによ り，帯電列中の流動媒体の選択により多種類中からの 一種類の分離が可能であると考えられる。本装置を操 作する場合，実験条件と同じ条件で帯電列を得ておく 事と分離前に被分離粒子, 流動媒体粒子, 流動塔に十 分な除電を施しておくことが必要である。

[謝辞] 本研究の一部は（財）ホソカワ粉体工学振興 財団の研究助成によって行われたものである。ここに 記して感謝の意を表する。

\section{References}

1) Miyake, A. : "Recycling Technology and SystemPolymer Recycle-", Plastics Age, Japan, July Special Number, 111-126 (1992)

2) Miyake, A. : "Equipment and Technology in Plastics Recycling”, Plastics Age, Japan, July Special Number, 69 - 86 (1995)

3) Nakajima, Y. and T. Tanaka: "Triboelectric Separator for Plastics Sorting System", The Micromeritics, No. 28, 4-13 (1984)
4) Kleine-Kleffman, U., A. Hollstein and I. Stahl : "Electrostatic Separation Process for Mixed Plastic Waste", Plastics, Japan, 44, 44-47 (1993)

5) Nagata, K. : "Static Electricity", p. 6, Baifukan (1987)

6) Hirama, T., M. Tomita, T. Adachi and M. Horio : "Rate of Combustion and Elutriation in a Fluidized Bed Coal Combustion”, Kagaku Kogaku Ronbunshu, 7, 77 82 (1981) 